УДК $327.56(73: 477)$

DOI: 10.26693/ahpsxxi2019.01.117

\title{
КОНЦЕПТ ВІЙНИ ТА МИРУ У ПРОМОВАХ ДОНАЛЬДА ТРАМПА ТА ВОЛОДИМИРА ЗЕЛЕНСЬКОГО
}

\author{
Олександр Шевчук, \\ e-mail: shevchukovo7@gmail.com \\ ORCID: https://orcid.org/oooo-Ooo3-0335-6873 \\ Чорноморсъкий національний університет ім. П. Могили, \\ Україна, 540оо, м. Миколаїв, вул. 68 Десантників, 10 \\ Олена Кравченко, \\ e-mail:voice.elena@gmail.com \\ ORCID: https://orcid.org/oooo-ooo3-2751-4485 \\ Чорноморсъкий національний університет ім. П. Могили, \\ Україна, 540оо, м. Миколаїв, вул. 68 Десантників, 10
}

У статті здійснюеться спроба виокремити концепт війни та миру у президентських промовах Володимира Зеленсъкого та Дональда Трампа та зробити порівняння цих позицій. Для аналізу використовуються інавгураційні промови та промови на Генеральній Асамблеї ООН у вересні 2019 року.

Загальний висновок в результаті роботи полягає в тому, що за наповненістю промови двох президентів є досить схожими за стилістикою та трансльованими меседжами, хоча, звичайно, і мають відмінності.

Ключові слова: промова, ООН, Дональд Трамп, Володимир Зеленський

Публічні виступи є одним з найдавніших механізмів діяльності політиків, в сучасному світі вони $є$ постійним компонентом політичної діяльності президента країни. Політична промова є однією з найпопулярніших форм публічного виступу та способу вираження політичного вектору того, чи іншого очільника держави. Політична промова орієнтована на чітку мету - вплинути на status quo, змінити баланс сил, тощо. Вона є засобом політичної боротьби (за посилення чи послаблення впливу на владні структури, суспільну думку, інституції). У будь-якому разі вона потенційно орієнтована на зміну або підтримку поточної політичної ситуації, на перерозподіл або підтримку існуючого балансу сил влади. Її базовою інструментальною функцією $є$ боротьба за владу. В межах всього соціуму вона виконує функцію інтеграції та диференціації.

Промова має на меті й тактичні цілі, сприяє вирішенню завдання актуального політичного життя, боротьби: подання інформації, дотримання певного політичного курсу, сприяє прийняттю або неприйняттю певних рішень, впливає на конкретних людей, організації тощо. Президентські промови є одним з інструментів утвердження способу життя країни, інформування, реалізації стратегічних завдань, тощо.

У сучасному політикумі вже неодноразово зустрічалися порівняння президентів США Дональда Трампа та України Володимира Зеленського стосовно способів вираження думок та творення політичної реальності. Навіть їх передвиборчі кампанії за інструментарієм та методами є дуже схожими. Поглиблене вивчення публічних промов цих президентів дасть змогу виявити ті чинники, на яких традиційно базується внутрішня та зовнішня політика, складовими яких є питання війни та миру, чим i обумовлена актуальність дослідження.

У даній статі автори роблять спробу об'єктивного аналізу концепту війни та миру, які відображаються крізь призму процесів глобалізації в американській та українській зовнішній політиці. Актуальність проблеми для українського соціуму зумовлена 
тим, що розуміння політичних традицій як механізму впливу на формування зовнішньої політики країни дає змогу з'ясувати спонукальні мотиви поведінки президентів i, відповідно, вироблення стратегії відносин у питаннях війни та миру. США мають суттєвий вплив на вектор розвитку України від початку проголошення ії̈ незалежності й дотепер. Крім того, входження нашої країни до кола світової спільноти, долучення ії до глобальних трансформаційних процесів XXI століття та формування власних політичних процесів потребує цілісного аналізу та ефективного стратегічного реагування, що є можливим за умови врахування політичних традицій провідних світових акторів, у першу чергу, Сполучених Штатів.

Для аналізу обрано інавгураційні промови президентів США та України та промови 3 74-ї сесії Генеральної Асамблеї ООН у вересні 2019 року.

Розглядаючи інавгураційні виступи Дональда Трампа та Володимира Зеленського, слід зазначити, що їх можна об'єднати темою популізму. Сьогодні питання популізму у політичному житті стає дедалі актуальнішим та важливішим. Президентів США та України вже не раз медіа порівнюють у своїх популістичних закликах. Заклики подолати бідність, врятувати країну «тут і зараз», питання про майбутнє дітей, певне залякування взагалі - все це способи отримати лояльну аудиторію та зіграти на емоційному стані виборця, який знаходиться у стресовій ситуації перед вибором майбутнього для своєї країни.

Порівнюючи інавгураційні промови на предмет популістичних маркерів, варто виокремити деякі положення.

Манера мовлення В. Зеленського у зверненнях до народу за своєю структурою і манерою дуже схожа на манеру американських президентів. Свого часу американський журналіст К. Вудворд виділив кілька принципів створення гарної інавгураційній промові: скромність («це наша спільна перемога»), впевненість («я зроблю все»), ефектні риторичні прийоми («я робив все, щоб українці посміхалися, а тепер зроблю все, щоб вони більше не плакали») і відсилання до славного минулого країни і до національної гордості громадян ${ }^{1}$. Але найбільше виступ Зеленського, мабуть, схожий на інавгураційну промову Д. Трампа, яку він виголосив у січні 2017 року. $Є$ практично дослівні повторення. Ось деякі з них.

В. Зеленський: «Крім війни, є ще багато бід, які роблять українців нещасними. Шокуючі тарифи, які принижують зарплати і пенсії, хворобливі ціни, неіснуючі робочі місця. Це медицина, про поліпшення якої в основному говорять ті, хто ніколи не лежав $з$ дитиною в звичайній лікарні. Це міфічні українські дороги, які будуються і ремонтуються лише в чиїсь бурхливій уяві»². Натомість цитата Д. Трампа: «Американці хочуть, щоб їхні діти навчалися в чудових школах, сім”і жили в безпечних районах, і хочуть, щоб у них була хороша робота. Але занадто багато хто з наших громадян живуть в іншій реальності: матері і діти погрузли в бідності в наших нетрях; проржавілі фабрики, як надгробки, розкидані по просторах країни; система освіти, переповнена грошима, випускає в життя наших молодих і прекрасних учнів без будьяких знань; злочинність, банди і наркотики забрали занадто багато життів»3.

Тобто, ми бачимо намагання розчулити аудиторію, згадуючи про найбільш незахищені прошарки населення. Називаючи вголос розміри тарифів, можна розізлити будь-якого українця, але економічне обгрунтування того чи іншого явища роз'яснювати не поспішають.

В. Зеленський: «Громадяни втомились від досвідчених, системних, надутих політиків, які за 28 років створили країну можливостей. Можливостей «відкатів», «пото-

\footnotetext{
${ }^{1}$ Woodward, C. (2017, January 19). Inaugural speeches a catalog of plodding oratory, with gems. The Associated Press. Retrieved from https://apnews.com/b3a3f7d500874be4a7doao4336f7f403

${ }^{2}$ Інавгураційна промова Зеленського. (2019, 20 травня). Радіо Свобода. Retrieved from https://www.radiosvoboda.org/a/news-promova-zelenskoho/29952433.html

3 The White House. (2017, January 20). The Inaugural Address. Retrieved from https://www.whitehouse.gov/briefings-statements/the-inaugural-address/
} 
ків», «дерибанів»4. Д. Трамп: «Ми більше не допустимо в уряді політиків, які тільки базікають, але нічого не роблять. Час порожніх розмов минув»5.

Бачимо, що йде повне відпрацювання «нового обличчя», яке зовсім не асоціюється з політичною елітою і може змінити країну на краще.

I Д. Трамп, і В. Зеленський роблять наголос на символічній передачі влади від самої влади - народу. Д. Трамп говорить про це прямо: «Сьогодні ми не тільки передаємо владу від однієї адміністрації інший або від однієї партії іншій - ми відбираємо владу у Вашингтона і передаємо її назад тобі - народ Америки» 6 . В. Зеленський використовує красиву метафору: «Кожен з нас президент!».

Тут явно відслідковується образ «свого хлопця», який з народом має спільні проблеми. Обидва вони обіцяють зробити все, щоб нарешті вирішити проблеми, від яких втомилося суспільство. «Я буду боротися за вас кожну секунду, і я ніколи-ніколи не підведу вас», - каже Дональд Трамп7. «Для того, щоб наші герої більше не гинули, я готовий на все», - обіцяє В. Зеленський ${ }^{8}$ Ця частина його промови - про припинення війни на сході - викликала найбільше домислів і припущень: на що саме він готовий? Про яку можливу репутаційну жертву йдеться? Багато угледіли тут проросійський вектор.

I Д. Трамп, і В. Зеленський роблять наголос на єдності нації, країни. I знову їх висловлювання дуже схожі.

Обидва вони завершують свої промови закликом до дій, які треба здійснювати прямо зараз. I цим самим створює точку відліку, як от Д. Трамп: «Усе це зміниться 3 цього дня. Саме тут. Бо цей момент - ваш момент. Він належить вам. Він належить усім, хто прийшов сюди, і усім, хто дивиться нас по всій Америці»9. В. Зеленський йде ще далі - він їх здійснює, оголошуючи про розпуск Верховної Ради, про підписання ряду законів і про декілька відставок. Меседж «зробимо їх разом» знаходить своє відображення у промові, і як наслідок, діях ${ }^{10}$. Хоч Президент США і нічого не розпускав, але дуже важлива деталь - дати можливість аудиторії зрозуміти, що з сьогоднішнього дня почнеться відлік до чогось важливого, що сьогоднішній момент особливий. Часто і цей відлік може увійти у нездійснені обіцянки і його можуть забути (для політика бажано, щоб так і сталося).

Іншими словами, очевидно, що В. Зеленський, складаючи свою промову, орієнтувався саме на західний стандарт, на тих, з ким його порівнюють. Саме тому його виступ так несхожий на ті, що до сих пір чули жителі пострадянського простору.

Якщо звернутися до контент-аналізу промови, то, за підрахунками авторів, у В. Зеленського вона може вважатися досить егоцентричною, адже слово «я» використовується 26 разів, а слово «ми» 20 разів. Промова написана простою мовою, і складається з простих для розуміння речень.

Слово «Україна» В. Зеленський сказав 16 разів, а «президент» і «ви» - по 10 разів. На початку промови В. Зеленський сказав, що кожен з нас президент, тому що перемога спільна. Також він підкреслив, що президент - це «не ікона, що не ідол», і закликав чиновників не вішати його портрет в кабінетах.

Слово «війна» в промові В. Зеленського звучало чотири рази, була, зокрема, фраза «Не ми почали цю війну. Але нам цю війну закінчувати». Три рази він згадав Донбас і один раз Крим, загальний посил: це все - українські землі ${ }^{11}$.

4 Інавгураційна промова Зеленського.(2019, 20 травня). Paдіо Свобода. Retrieved from https://www.radiosvoboda.org/a/news-promova-zelenskoho/29952433.html

5 The White House. (2017, January 20). The Inaugural Address. Retrieved from https://www.whitehouse.gov/briefings-statements/the-inaugural-address/

6 Ibidem.

7 Ibidem.

8 Інавгураційна промова Зеленського. (2019, 20 травня)...

9 The White House. (2017, January 20). The Inaugural Address...

${ }^{10}$ Інавгураційна промова Зеленського. (2019, 20 травня)...

${ }^{11}$ Ibidem. 
По одному разу президент сказав про переселенців і заробітчан. Уряд удостоївся в промові В. Зеленського більше уваги, це слово прозвучало три рази, причому в контексті, що він не вирішує проблеми українців. «І я не розумію наш уряд, який тільки розводить руками і каже: ми нічого не можемо зробити. Неправда. Можете. Ви можете взяти листок, взяти ручку і звільнити свої місця для тих, хто буде думати про наступні покоління, а не про наступні вибори», - сказав В. Зеленський ${ }^{12}$.

При цьому В. Зеленський не згадав про економіку і освіту. Слово «реформи» теж не звучало жодного разу.

Контент-аналіз інавгураційної промови Д. Трампа 2016 р. показує, що промова написана простою мовою, яка за стилістичним оформленням та синтаксичною структурою більше підходить для випускників середньої школи, а не для студентів вищих навчальних закладів ${ }^{13}$.

Патріотичний поклик «Америка» та «американський» переважає всіх попередників Трампа по кількості згадування. Заклик до надання надзвичайного статусу громадянам США та об’єднання читається у фразі «Ми, жителі Америки, разом визначимо курс Америки та всього світу на наступні роки».

За підрахунками авторів, слово «ми» та його варіанти використовується у промові 95 разів, «ти» та його похідні 19 разів. Слово «вони» прозвучало 5 разів, а егоїстичне «я» всього лише 3, проти 26 в українського президента.

Найбільш трансльованою емоцією у промові Д. Трампа можна визначити «успіх», у промові В. Зеленського - «згуртування» та «консолідація», що обумовлюється політичною реальністю країн, виступи очільників яких підлягали аналізу.

Наступним матеріалом для аналізу виступають промови президентів Д. Трампа та В. Зеленського на 74-й сесії Генеральної Асамблеї ООН у вересні 2019 року.

Генеральний секретар ООН А. Гутерріш, звертаючись до учасників загальнополітичної дискусії під час відкриття 74-ї сесії Генеральної Асамблеї ООН, окреслив головні проблеми, що стоять перед людством, і наголосив на ролі ООН у їх розв'язанні. На його думку, у міжнародних відносинах назріває нова загроза, яка, можливо, ще не набула значних масштабів, але є цілком реальною. Це «великий розлом» - розділення світу на два конкуруючі між собою табори, які утворяться навколо двох держав 3 найпотужнішими економіками. А. Гутерріш закликав зробити все, щоб не допустити «великого розлому» та зберегти універсальну економіку, засновану на повазі міжнародного права, і багатополярний світ із сильними багатосторонніми інститутами. За словами глави ООН, ключ до запобігання конфліктам і загального процвітання це безумовне дотримання прав людини. Однак сьогодні, за словами Генсека, багато які із цих прав безкарно порушуються або ставляться під сумнів. А. Гутерріш наголосив також на необхідності ліквідації дискримінації жінок і забезпечення повноправної участі їх у політичному й громадському житті, підкреслив важливість зусиль людства щодо боротьби зі зміною клімату14.

Президент США Д. Трамп у своїй промові 24 вересня 2019 р. визначив національними пріоритетами: нелегальну міграцію, боротьбу з трафіком людей, реформу системи світової торгівлі. «Майбутнє належить не глобалістам, майбутнє належить патріотам. Мудрі лідери завжди ставлять на перше місце інтереси свого народу і своєї країни», - підкреслив Д. Трамп ${ }^{15}$. Фактично, це була чергова презентація його філософії «Америка понад усе». Він підкреслив, що завдяки його економічній політиці в США зростають доходи населення й знижується рівень безробіття та бідності.

12 Інавгураційна промова Зеленського. (2019, 20 травня)...

13 Trump speech analysis: What words tell us about the 45th president. (2017, May 16). Retrieved from https://expertsystem.com/trump-speech-analysis/

${ }_{14}$ Новости ООН. Необходимо избежать разделения мира на два конкурирующих лагеря Генеральный секретарь ООН. (2019, 24 сентября). Retrieved from https://news.un.org/ru/story/2019/o9/1363502

15 Kumar, A. (2019, September 24). Decoding Trump's speech before the United Nations. Politico. Retrieved from https://www.politico.com/story/2019/o9/24/trump-speech-at-un-1507923 
Тим не менш, завдяки «інтересам свого народу» у 2019 році на військові потреби 3 бюджету було витрачено 2,5 трлн доларів, і це для Д. Трампа є ідентифікатором «наймогутнішої нації світу» ${ }^{6}$.

Одна з головних загроз міжнародній безпеці сьогодні - це «репресивний» режим в Ірані, заявив Д. Трамп. Він підкреслив, що іранська влада «спонсорує» тероризм, «підживлює» війни в Сирії і Ємені, витрачає національне багатство в спробах створити ядерну зброю. «Жоден поважний уряд у світі не повинен фінансувати іранську жагу до крові. Цього не можна допустити», - наголосив Д. Трамп, нагадавши про вихід США з іранської ядерної угоди 2015 р. та введені проти Ірану санкції ${ }^{17}$. Він підкреслив, що санкції не буде скасовано, поки Іран не припинить вести себе агресивно. Таким чином, питання тероризму досі займає одну з провідних позицій на порядку денному на міжнародній політичній арені.

Нелегальна міграція давно є лейтмотивом політичного курсу Президента США. Його меседж до нелегалів звучав так: «Не платіть контрабандистам, не наражайте себе на небезпеку своїми діями, якщо вам не дозволено бути тут. Вас негайно повернуть додому. Ми захистимо свої кордони ${ }^{18}$. Тобто, напруження у стосунках 3 емігрантами залишається стійким, і мирне врегулювання цього питання за президентства Д. Трампа не передбачається.

Президент США висловив надію на «відновлення демократії» у Венесуелі та перемогу «свободи» в регіоні. Д. Трамп називає Н. Мадуро диктатором і «кубинським цуциком» і закликає народ Венесуели пам'ятати, що «Америка з вами». За його словами, найбільшу загрозу для країн регіону представляє соціалізм, який, на його думку, «руйнує нації»19. Але слід пам'ятати, про те, що для США це більше питання поділу сфер впливу в Латинській Америці, а не проблема добробуту для венесуельців. Заклик на початку промови до того, що найбільш стабільною у питаннях війни та миру є та країна, яка, в першу чергу, зважає на власні інтереси, це прекрасно демонструє.

«Америка знає, що в той час, як кожен може вести війну, лише найсміливіший може обрати мир. Саме тому ми дотримувалися сміливої дипломатії на Корейському півострові. Я казав Кім Чен Ину, що його країна має надзвичайний нерозкритий потенціал, але задля його реалізації Північна Корея повинна провести ядерне роззброєння ${ }^{20}$. По суті, Трамп у цій фразі має поведінку справжнього бізнесмена - не важливо з ким домовлятися, але треба домовитися. До речі, про Україну у промові президент Д. Трамп не згадував взагалі.

Президент України В. Зеленський 25 вересня виступив з промовою під час загальних дебатів сесії Генасамблеї ООН, а також узяв участь у саміті щодо Цілей сталого розвитку. У своїй промові Президент України висловив надію, що завдяки підтримці міжнародних партнерів вдасться домогтися повернення українських територій і припинення війни на Донбасі. Він заявив, що в сучасному світі немає «чужих воєн»21.

В. Зеленський нагадав, що війна на Донбасі триває вже п’ять років. «П'ять років минуло з тих пір, як Росія окупувала український Крим. Сьогодні, коли існують тисячі сторінок міжнародного права та сотні організацій, покликаних його захищати, наша, саме наша країна зі зброєю в руках, втрачаючи своїх громадян, відстоює власний суверенітет і територіальну цілісність», - підкреслив Президент України⒉

${ }^{16}$ Kumar, A. (2019, September 24). Decoding Trump's speech before the United Nations...

17 The White House. (2019, September 25). Remarks by President Trump to the 74th Session of the United Nations General Assembly. Retrieved from https://www.whitehouse.gov/briefingsstatements/remarks-president-trump-74th-session-united-nations-general-assembly/

18 Ibidem.

19 Ibidem.

${ }^{20}$ Kumar, A. (2019, September 24). Op. cit.

${ }^{21}$ Офіс Президента України. (2019, 25 вересня). Виступ Президента Украйни Володимира Зеленського на загальних дебатах 74-ї сесї Генеральної Асамблеї ООН. Retrieved from https://president.gov.ua/news/vistup-prezidenta-ukrayini-volodimira-zelenskogo-na-zagalnih-57477 22 Ibidem. 
Президент України заявив, що його головна мета - припинення війни, повернення всіх українських окупованих територій і відновлення миру. «Але не ціною життя наших громадян, не ціною свободи чи права України на власний вибір. Саме тому ми потребуємо світової підтримки, - підкреслив український Президент. - Я розумію: всі присутні тут мають власний державний клопіт. I чужі проблеми не повинні хвилювати вас більше, ніж власні. Але в сучасному світі, де ми з вами живемо, більше немає чужої війни. I ніхто з вас не зможе почувати себе у безпеці, коли йде війна в Україні, коли йде війна в Європі». За його словами, позиція «нас це не стосується і ніколи не торкнеться» може стати фатальною, адже небажання поступитися власними амбіціями зрештою обходиться загибеллю десятків мільйонів людей 23.

«Невже людство почало забувати страшні уроки історії», - звернувся до аудиторії В. Зеленський, нагадавши про жахи світових воєн. Натомість зауважив, що «Україна завжди демонструвала світу готовність забезпечувати мир цивілізованим шляхом. I робила кроки на шляху до міжнародної безпеки. Наприклад, коли відмовилася від ядерного потенціалу, що на той час був більшим, ніж у Великої Британії, Франції та Китаю разом узятих. Врешті-решт наша держава втратила частину своїх територій та майже щодня втрачає своїх громадян»24.

Водночас В. Зеленський застеріг світових лідерів від думки, що війна десь далеко. «Методи її ведення, технології та озброєння призвели до того, що наша планета вже не така велика. I сьогодні часу, який я витратив на останній абзац, достатньо, щоб зруйнувати Землю вщент. Це значить, що на кожного лідера лягає відповідальність не лише за долю власної країни, а й за долю всього світу. На мою думку, нам всім потрібно усвідомити, що сильний лідер не той, хто, не моргнувши оком, відправляє тисячі солдатів на вірну смерть. Сильний лідер той, хто береже життя кожної людини», - зазначив В. Зеленський 25.

Він висловив жаль, що й досі суперечки між державами все ще вирішуються за допомогою ракет, а не слів. В. Зеленський додав, що у війні не можна домогтися перемоги: «Ті, хто виграють війну, ніколи не припиняють воювати». Тому Президент України закликав, усвідомлюючи всю небезпеку цивілізації, «генерувати інші смисли. I боротися за нову людську ментальність, де агресія, гнів і ненависть будуть атрофованими почуттями» ${ }^{26}$. Стратегія С. Кові - «виграш-виграш», але можливість ії реалізації у сучасному політичному світі викликає сумніви ${ }^{27}$. Пацифізм має право на існування, але він не може бути таким наївним.

Під час участі в діалозі лідерів на саміті ООН з питань Цілей сталого розвитку в рамках 74-ї сесії Генасамблеї ООН Президент України В. Зеленський висловив сподівання, що завдяки підтримці міжнародних партнерів вдасться досягнути повернення українських територій політико-дипломатичним шляхом, припинення війни та встановлення миру. «Жодна держава не досягне сталого розвитку без миру та відчуття безпеки. Сталий розвиток неможливий під звуки пострілів і вибухів, неможливий там, де панують агресивні геополітичні стратегії, що аплодують вторгненню до інших держав і порушенню прав і свобод людини», - наголосив В. Зеленський ${ }^{28}$.

Президент запевнив, що Україна віддана своїм зобов'язанням щодо Цілей сталого розвитку - для їх досягнення створено національні стратегічні рамки, функціонує механізм упровадження цілей і моніторингу цього процесу. «Нашими завданнями $\epsilon$

23 Офіс Президента України. (2019, 25 вересня). Виступ Президента Украӥни Володимира Зеленсъкого на загальних дебатах 74-ї сесї Генеральної Асамблеї ООН. Retrieved from https://president.gov.ua/news/vistup-prezidenta-ukrayini-volodimira-zelenskogo-na-zagalnih-57477 24 Ibidem.

25 Ibidem.

${ }^{26}$ Ibidem.

${ }_{27}$ Кові, С.P. (2012). 7 звичок надзвичайно ефективних людей. Харків: Клуб сімейного дозвілля. Retrieved from https://coollib.com/b/338636/read

28 Тарасенко, Н. (2019). Міжнародні зустрічі та заяви Президента України В. Зеленського на полях 74-ї сесії Генасамблеї ООН. Україна: подй, факти, коментарі, 19, 10. 
істотне зростання економіки задля подолання бідності та підвищення зайнятості населення, дієва реформа правоохоронних і судових органів, завершення реформи децентралізації», - зазначив глава держави ${ }^{29}$. Водночас, за його словами, показники України можуть і повинні бути значно кращими, адже країна обрала правильний шлях розвитку. «На цьому шляху сьогодні два бар'єри. Перший - це внутрішньополітична традиція, коли важливі для розвитку реформи отримують спротив. Але 3 цим нова українська влада обов’язково впорається. Другий бар'єр набагато складніший. I нам його не подолати без міжнародної підтримки. Це війна внаслідок російської агресії проти України», - наголосив В. Зеленськийзо. Ця заява є надзвичайно важливою, оскільки вперше публічно Зеленський називає Росію країною-агресором.

В. Зеленський висловив сподівання, «що разом з міжнародними партнерами політико-дипломатичним шляхом ми зможемо домогтися повернення наших територій, припинення війни та панування миру». «I це - наша мета номер один. Для того щоб пліч-о-пліч з державами-членами ООН ми без бар'єрів могли рухатися вперед для досягнення інших Цілей сталого розвитку та разом будувати новий світ, вільний від бідності, голоду, захворювань і війн», - резюмував Президент Україниз1.

У промовах, виголошених під час заходів на сесії Генасамблеї ООН, В. Зеленський озвучив свої пріоритети щодо подальшого економічного розвитку країни, прагнення завершити війну на Донбасі політико-дипломатичним шляхом та відновити територіальну цілісність України, у зв'язку з чим висловив сподівання на співпрацю з міжнародними партнерами. Але загалом, зовнішньополітичний вектор Президента України на Генеральній Асамблеї ООН не можна назвати взірцем вивіреної політики, адже конкретна стратегія у його діях відсутня, і наступний крок передбачити важко. У промовах зберігається тенденція до популізму та пацифізм зі сподіванням врегулювати все мирно і без втрат.

Слід зазначити, що риторика президентів США та України є схожою за своєю структурою та стилістикою мовлення - адже мовні оберти та сама суть речей висловлюється простою мовою, подекуди, розмовною. Звичайно, різною є наповненість промов, оскільки В. Зеленський просить про допомогу у міжнародної спільноти і закликає до консолідації власне української нації, а Д. Трамп щоразу підкреслює велич американців та їх значимість у будь-якому своєму політичному рішенні. Пацифічна риторика присутня у промовах кожного президента, але у В. Зеленського вона виглядає дещо наївною і $є$ благанням про допомогу, а Д. Трамп використовує іï задля подальшої економічної вигоди, по суті, маючи модель поведінки бізнесмена.

Отже, що в реаліях сьогодення питання війни та миру є надзвичайно важливим для усіх політичних лідерів, надто тих країн, на чиїх територіях дійсно відбуваються воєнні дії. Питання у тому, якими методами буде досягнений компроміс залишається відкритим.

\section{REFERENCES}

Inavhuratsiina promova Zelenskoho. (2019, 20 travnia). [The inaugural speech of Zelenskyy]. Radio Svoboda. Retrieved from https://www.radiosvoboda.org/a/news-promovazelenskoho/29952433.html [in Ukrainian]

Kovi, S.R. (2012). 7 zvychok nadzvychaino efektyvnykh liudei. [The 7 Habits of Highly Effective People]. Kharkiv: Klub simeinoho dozvillia. Retrieved from https://coollib.com/b/338636/read [in Ukrainian]

Kumar, A. (2019, September 24). Decoding Trump's speech before the United Nations. Politico. Retrieved from https://www.politico.com/story/2019/09/24/trump-speech-at-un-1507923 [in English]

Novosti OON. Neobkhodimo izbezhat razdeleniia mira na dva konkuriruiushchikh lageria Generalnyi sekretar $O O N$. (2019, 24 sentiabria). [The necessity to avoid dividing world into two competing camps]. Retrieved from https://news.un.org/ru/story/2019/09/1363502 [in Russian]

29 Офіс Президента України. (2019, 25 вересня). Виступ Президента Украӥни Володимира Зеленського на загальних дебатах 74-ї сесї Генеральної Асамблеї ООН...

$3^{30}$ Ibidem.

${ }^{31}$ Ibidem. 
Ofis Prezydenta Ukrainy. (2019, 25 veresnia). Vystup Prezydenta Ukrainy Volodymyra Zelenskoho na zahalnykh debatakh 74-i sesii Heneralnoi Asamblei OON. [The address of Ukraine's president Volodymyr Zelenskiy in general debates in 74th UN General Assembly]. Retrieved from https://president.gov.ua/news/vistup-prezidenta-ukrayini-volodimira-zelenskogo-na-zagalnih57477 [in Ukrainian]

Tarasenko, N. (2019). Mizhnarodni zustrichi ta zaiavy Prezydenta Ukrainy V. Zelenskoho na poliakh 74-i sesii Henasamblei OON. [International meetings of Ukraine's president V. Zelenskiy in 74th UN General Assembly]. Ukraina: podii, fakty, komentari, 19, 4-13. [in Ukrainian]

The White House. (2017, January 20). The Inaugural Address. Retrieved from https://www.whitehouse.gov/briefings-statements/the-inaugural-address/ [in English]

The White House. (2019, September 25). Remarks by President Trump to the 74th Session of the United Nations General Assembly. Retrieved from https://www.whitehouse.gov/briefingsstatements/remarks-president-trump-74th-session-united-nations-general-assembly/ English]

Trump speech analysis: What words tell us about the 45th president. (2017, May 16). Retrieved from https://expertsystem.com/trump-speech-analysis/ [in English]

Woodward, C. (2017, January 19). Inaugural speeches a catalog of plodding oratory, with gems. The Associated Press. Retrieved https://apnews.com/b3a3f7d500874be4a7doa04336f7f403 [in English]

Oleksandr Shevchuk, Petro Mohyla Black Sea National University, Mykolaiv, Ukraine ORCID: https://orcid.org/oooo-Ooo3-0335-6873

Olena Kravchenko, Petro Mohyla Black Sea National University, Mykolaiv, Ukraine ORCID: https://orcid.org/oOOO-OOO3-2751-4485

\section{«War and peace» issue in speeches of Donald Trump and Volodymyr Zelenskyy}

In the article, authors show key issues about «war and peace» in public speeches of US President Donald Trump and Ukraine President Volodymyr Zelenskyy. Analyzing their policies and instruments authors find out that they have some similarities, such as populists' appeals, stylistic constructions, pacific rhetoric, national identity, and unity, etc.

Presidential speech is one of the instruments to approve the county's way of life, to inform, to realize strategic plans, etc.

Nowadays ones compare president Trump and president Zelenskyy according to their way of thinking and implementation of political activities. Even their pre-election campaigns had similar methods, technologies, and management. In-depth speech study of these presidents gives an opportunity to identify the factors on which traditionally base domestic and foreign policy, which components are «war and peace» topic that determines the relevance of the study.

In the article, authors make an effort to analyze objectively «war and peace» issue, which is described by the globalization process in American and Ukrainian foreign policies. The USA has had a great impact on Ukraine's development direction since its independence proclamation till today. Moreover, our country's world integration, its joining to the global transformation in XXI century and formation of its own political processes need complex analysis and effective strategic reaction that could be possible in the condition of taking into account political traditions of providing world actors, first of all, USA.

It should be highlighted that the rhetoric of US and Ukraine presidents is compatible with its syntactic structure and stylistic. Even language constructions and the bottom lines are spoken by simple short phrases, mostly common spoken language. Definitely, the essence of speeches is different because V. Zelenskyy is asking about the international community's help and guiding and calls for Ukrainian nation unity, but D. Trump talks 
at most about Americans' greatness and their significance in any his political decision. Pacific rhetoric is presented in both speeches, but V. Zelenskyy uses it in a little naïve way and it is comparable to begging for help and D. Trump uses it for forwarding economic benefits, in fact, implementing his businessman behavior.

Thus, reality shows that the "war and peace» issue is truly important for all political leaders, especially, for those countries where are took place military actions. The question is in what methods this compromise should be reached.

Keywords: speech, UN, Donald Trump, Volodymyr Zelenskyy 